\title{
O Estado Plurinacional da Bolívia e as garantias constitucionais à reafirmação das horizontalidades geográficas
}

\author{
Rubens de Toledo Junior \\ Universidade Federal da Integração Latino-Americana - Foz do \\ Iguaçu - PR - Brasil \\ ORCID: https://orcid.org/0000-0002-8387-0970 \\ Luiz Fernando Ribeiro de Sales \\ Universidade Federal da Integração Latino-Americana - Foz do \\ Iguaçu - PR - Brasil \\ ORCID: https://orcid.org/0000-0001-7989-8834
}

\section{Resumo}

Nos primeiros anos do século XXI, ocorreu na Bolívia um conjunto de transformações políticas, jurídicas, econômicas e territoriais. Naquele momento a Bolívia promoveu uma assembleia constituinte com o intuito de refundar o Estado, colocando-o a serviço das demandas populares, principalmente na construção de um Estado integral (LINERAb, 2010), da descolonização, integração territorial e nacionalização dos recursos naturais. Nesse sentido foi fundado o Estado Plurinacional da Bolívia, como aposta de solução aos conflitos territoriais do país. Em face disso, este trabalho deseja saber quais são as garantias constitucionais promulgadas pela constituição de 2009 no processo de reafirmação das horizontalidades geográficas. Trata-se de um estudo interdisciplinar entre o Direito e a Geografia, cuja metodologia foi de pesquisa bibliográfica e análise de documentos, estruturados a partir da categoria de espaço geográfico de Milton Santos (2006) e das premissas do Novo Constitucionalismo Latino-Americano, por seus diversos expoentes, especialmente Rubén Martinez Dalmau e Roberto Viciano Pastor (2012).

Palavras-chave: Estado Plurinacional da Bolívia. Espaço Geográfico. Constitucionalismo Latino-Americanismo.

The Bolivian Plurinational State and the constitutional assurances for the reaffirmation of Abstract geographical horizontalities

In the early years of the XXI Century, Bolivia a set of political, legal, economic and territorial transformations. At this time, Bolivia promoted a Constitutional Assembly in order to refound the State, putting it in the service of popular demands, mainly in the construction of a new integral State (LINERA, 2010), in decolonization, territorial integration, and nationalization of natural resources. In this sense, the Plurinational State of Bolivia was founded, as an answer to the territorial conflicts of the country. In this context, this work 
aims to verify the constitutional assurances promulgated by the Constitution of 2009 in the process of reaffirming the geographical horizontalities. This work is an interdisciplinary study in Law and Geography, whose methodology was bibliographic research and document analysis, especially regarding Milton Santos' geographical space category (2006) and the New Latin-American Constitutionalism, of Rubén Martínez Dalmau and Roberto Viciano Pastor (2012).

Keywords: Plurinational State of Bolivia. Geographical space. Latin-American Constitutionalism.

\section{El Estado Plurinacional de Bolívia y las garantías constitucionales a la reafirmación de las horizontalidades geograficas}

\section{Resumen}

En los primeros años del siglo XXI, se produjo en Bolivia un conjunto de transformaciones políticas, jurídicas, económicas y territoriales. En ese momento Bolivia promovió una asamblea constituyente con el objetivo de reformular el Estado, dejando al servicio de las demandas populares, principalmente en la construcción de un Estado Integral (LINERA, 2010b), de la descolonización, integración territorial y nacionalización de los recursos naturales. En ese sentido fue fundado el Estado Plurinacional de Bolivia, como una apuesta de solución a los conflictos territoriales del País. En razón de eso, este trabajo desea saber cuales son las garantías constitucionales promulgadas por la constitución de 2009 en el proceso de reafirmación de las horizontalidades geográficas. Se trata de un estudio interdisciplinar entre el derecho y la geografía cuya metodología fue la de pesquisa bibliográfica y análisis de documentos, estructurados a partir de la categoría de espacio geográfico de Milton Santos (2006) y de las premisas del Nuevo Constitucionalismo Latinoamericano, por sus diferentes exponentes, especialmente Rubén Martínez Dalmau y Roberto Viciano Pastor (2012).

Palabras claves: Estado plurinacional de Bolivia. Espacio geográfico. Constitucionalismo Latinoamericano.

\section{Introdução}

O presente trabalho é um estudo interdisciplinar entre o Direito e a Geografia e tem como objetivo averiguar de que modo as reivindicações territoriais por parte de agentes invisibilizados desaguaram no texto constitucional de 2009 e quais ferramentas este prevê no processo de disputa pelo uso do território, e compôs parte de investigações em curso no curso de mestrado em Estudos LatinoAmericanos da Universidade Federal da Integração Latino-Americana.

Esse diálogo interdisciplinar se justifica em razão de que as análises territoriais têm uma dimensão que complementa aquela realizada pelo Direito, por melhor expor seus aspectos políticos, de relações de poder. Também é possível questionar como o direito positivo se relaciona com essas estruturas como legitimador e normatizador de determinada acepção de uso do território em detrimento de outras.

Após um conturbado período de efervescência e protestos sociais-populares ante os resultados deletérios da hegemonia neoliberal, nos idos dos anos 2000, com marcantes episódios, tais como a Guerra da Água (2000) e do Gás (2003), a Bolívia testemunhou o ocaso final desta agenda macroeconômica e a ascensão social de estratos sociais historicamente marginalizados, indígenas e mineiros, ao poder central, com a vitória eleitoral de Evo Morales em 2005, vindo a se conformar uma hegemonia subalterna entre indígenas, camponeses e mineiros que ficou 
conhecida como indígena-popular (VALENÇA, 2018) (CUNHA-FILHO, 2018). O desdobramento foi um conjunto de mudanças políticas, jurídicas, econômicas e territoriais. O nosso enfoque olhares sobre a estrutura constitucional buscando institutos jurídicos que potencializem o fortalecimento das horizontalidades, conceitualizadas nas próxunas páginas, num cotejo histórico-espacial e o novo texto constitucional. De modo mais direto, a partir de uma análise da história territorial da Bolívia do ano 2000 até apromulgação da constituição de 2009. Isso por dois motivos: do ponto de vista geográfico, há pouco tempo de vigência dessa nova geografia política para uma averiguração empírica a respeito de mudanças efetivas às dinâmicas territoriais, que será posta a prova em razão dos últimos incidentes vivenciados no pleito eleitoral do ano passado, que traz à tona o espectro do fantasma do golpe e da instanbilidade constitucional do País. E segundo, porque desde o objeto da pesquisa que este trabalho deriva, o enfoque é circunspecto ao esquadrilhamento da geografia política plurinacional consagrada na constituição, suprindo uma lacuna nos estudos jurídico-geográficos quanto ao tema.

Como veremos com a criação do Estado plurinacional, a perspectiva de um desenvolvimento regional na Bolívia se dá não apenas na busca por minimizar as desigualdades econômicas regionais, mas principalmente na garantia da autonomia étnica e culturais de diferentes parcelas de seu território ocupadas por diferentes nações.

Em que pese não tenha sido a causa de todos os questionamentos sociais vivenciados no país, visto que as raízes destes deitam suas origens no longo processo de produção colonial, o neoliberalismo representou o estopim final para a insurgência popular em busca da satisfação de reivindicações historicamente acumuladas, que, laconicamente, gravitavam em torno de direito à terra, ao território, de usos dos recursos naturais e da descolonização (VALENÇA, 2018).

E foram essas reivindicações que compuseram a cognominada "Agenda de Outubro", um plano político forjado pelos setores subalternos e assim batizado em homenagem ao período rebelde (2000-2005), a que o Movimiento al Socialismo (MAS), partido de Evo Morales, havia se comprometido a implementar, a partir da convocação de uma assembleia constituinte, com o fito de refundar o Estado desde uma perspectiva nacionalista e descolonial (LEONEL JUNIOR, 2018), (GALVÁN, 2010).

A promessa restou cumprida, pelo menos no que diz respeito à convocação de uma assembleia constituinte como mecanismo para o início da refundação do Estado, desde a vontade popular e não das históricas elites nacionais, resultando, após um tumultuado processo constituinte, na promulgação da Constituição Política do Estado de 2009, inserindo na história político-constitucional do País o inédito Estado Plurinacional da Bolívia.

Pelo ineditismo, em séculos, em resgatar a soberania popular e o papel democrático da constituição como ferramenta para a emancipação social, num claro uso contra-hegemônico de instrumentos hegemônicos (SANTOS, 2007), no presente caso da estrutura jurídica, essa experiência boliviana com 0 constitucionalismo democrático passou a ser cognominada de Novo Constitucionalismo Latino-Americano, da mesmo forma que em outras assembleias constituintes sul-americanas profundamente democráticas, tais como as resultadas nas Constituições de Colômbia (1991), Venezuela (1999) e Equador (2008), todas 
elas comprometidas com a emancipação, conforme sublinha Rubén Martínez Dalmau e Roberto Viciano Pastor (2012).

Segundo estes autores, as constituições advindas do que denominam de Novo Constitucionalismo Latino-Americano, se caracterizam, dentre outros atributos que veremos mais adiante, por serem constituições democráticas, o que implica dizer que são depositárias da vontade soberana do povo, profundamente preocupadas com a legitimidade democrática; normativas, visto apostarem na rigidez constitucional e centralidade da constituição no ordenamento jurídico e guia de ação dos poderes constituídos (deixando para trás o histórico de constituições nominalistas); autônoma, visto serem o produto de movimentos sociais e populares; necessárias e de transição.

No contexto boliviano, essa assembleia constituinte tinha o condão de iniciar uma transição de um Estado liberal, excludente, monocultural e aparente, como pontua Linera (2010b) a um Estado refundado, calcado na pluralidade, interculturalidade, plurinacionalidade, que veio ser concretizado no plano jurídicoconstitucional de Estado Plurinacional da Bolívia. Um processo de mudança descrito no preâmbulo dessa constituição democrática de 2009:

[...] El pueblo boliviano, de composición plural, desde la profundidad de la historia, inspirado en las luchas del pasado, en la sublevación indígena anticolonial, en la independencia, en las luchas populares de liberación, en las marchas indígenas, sociales y sindicales, en las guerras del agua y de octubre, en las luchas por la tierra y territorio, y con la memoria de nuestros mártires, construimos un nuevo Estado. [...]Dejamos en el pasado el Estado colonial, republicano y neoliberal. Asumimos el reto histórico de construir colectivamente el Estado Unitario Social de Derecho Plurinacional Comunitario, que integra y articula los propósitos de avanzar hacia una Bolivia democrática, productiva, portadora e inspiradora de la paz, comprometida con el desarrollo integral y con la libre determinación de los pueblos. (BOLÍVIA, 2009).

Os fragmentos do preâmbulo da Constituição de 2009 acima transcritos, deixam transparecer cabalmente a complexidade, a abrangência do labor, e as expectativas que esse novo Estado, agora plurinacional e comunitário, inspiram a população, como provedor, ademais de melhores condições de estrutura social, políticas e econômicas, de um uso democrático, contra hegemônico, descolonial e intercultural, portanto horizontal do território, ante o assédio de agentes políticoeconômicos e suas racionalidades transnacionais, verticais.

O trecho evidencia, ainda, a existência prévia de uma disputa territorial, de racionalidades no uso do território, entre elites econômicas veiculadas ao capitalismo global e agentes subalternos, tendo esse Estado Plurinacional a incumbência de assegurar a esses agentes um uso contra-hegemônico do território. A história da Bolívia é entrecortada por disputas territoriais, marcada por fragmentações territoriais (desenvolvimento desigual), baixa integração oriente/ocidente, dicotomia entre Estado aparente e Oligárquico como gestor do território num contexto de luta indígena, camponesa e popular por seu direito à terra e suas próprias territorialidades, situação essa em muito agravada pelo Estado Neoliberal, a despeito de alguns avanços, como veremos. 
Assim, no âmbito dessa especificidade territorial da história e do dever constitucional do Estado Plurinacional em corrigir as desigualdades territoriais, indaga-se quais são as garantias implementadas pela Constituição de 2009 no processo de emancipação das horizontalidades, como racionalidades e usos contrahegemônicos do território. Tem-se como marco teórico a teoria sobre o espaço geográfico desenvolvida por Milton Santos (2006), em que o espaço é uma instância social, dinâmica, rechaçando o caráter passivo, de mero receptáculo da sociedade, ao pontuar que o espaço é a síntese da ação humana e a materialidade que o cerca; e o Novo Constitucionalismo Latino-Americano, na perspectiva de Rubén Martínez Damau e Roberto Viciano Pastor (2012), em que a constituição democrática é a materialização da vontade do povo e comprometida com a emancipação, sempre nos limites do objeto proposto.

Mesmo decorridos mais de 10 anos da promulgação da constituição de 2009 e quase 10 anos da Lei Marco de Autonomias e Descentralização "Andrés Ibáñez", de 2010, fruto de imposição constitucional pela necessidade de instrumento infraconstitucional de desenvolvimento da geografia política plurinacional, optamos pela exposição da estrutura constitucional, isso porque ela constitui a base a partir da qual esse nova geografia política se funda, bem como em razão do pouco tempo de vigência dos novos dispositivos, podendo ser ainda prematuros estudos empíricos quanto ao tema.

Para tanto, o presente trabalho está estruturado da seguinte forma, a saber: primeiramente uma exposição sobre a categoria de espaço geográfico, num segundo momento uma discussão panorâmica sobre a formação e as disputas territoriais mais centrais da Bolívia até a deflagração do processo de cambio, com a constituição de 2009, e, por fim, uma análise normativa dos institutos e garantias constitucionais que podem servir de ferramenta para o fortalecimento de um uso horizontal do território.

\section{As raízes territoriais da Bolívia: verticalidades, desigualdades geográficas e a luta popular}

Para interpretar as condições que tornaram possíveis a transição de poder na Bolívia que se desdobrou na elaboração de sua Constituição atual, baseada no Novo Constitucionalismo Latino-Americano, devemos levar em conta o modo como o território deste país foi se configurando historicamente, o surgimento e ampliação das desigualdades sociais e territoriais, e finalmente os processos de resistência à globalização que caracterizam esta formação socioespacial.

É pela interação da formação socioespacial com o modo de produção capitalista que os diversos países respondem de forma particular aos vetores do modo de produção (SANTOS, 2005). Essas particularidades é que fazem a formação socioespacial aceitar ou oferecer diversos níveis de resistência a esses vetores. A configuração territorial nacional, constituída pela sucessão dos usos do território ao longo da história é que faz com que cada formação socioespacial tenha caractrísticas próprias, portanto é pela genealogia da formação socioespacial boliviana e sua inserção na América Latina que se dá a busca por desvendar os processos que propiciaram a implementação da atual constituição. 
Desde o encontro com os europeus, em 1492, os povos originários da América Latina foram submetidos ao flagelo da conquista, colonização e neocolonialismo no período subsequente à independência, pois "A partir dali [da colonização/conquista], as principais transformações nestas terras não derivariam de processos próprios aos autóctones, mas sim, de influências do capitalismo e geopolítica globais." (VALENÇA, 2018, p. 35), ou seja, de verticalidades (SANTOS, 2000), empreendendo, desde então, esses povos, lutas em resistência e oposição a esse projeto territorial.

Para Milton Santos (2000), "as verticalidades podem ser definidas, num território, como um conjunto de pontos formando um espaço de fluxos. A idéia, de certo modo, remonta aos escritos de François Perroux, quando ele descreveu o espaço econômico". Nesse sentido,

As frações do território que constituem esse espaço de fluxos constituem o reino do tempo real, subordinando-se a um relógio universal, aferido pela temporalidade globalizada das empresas hegemônicas presentes. Desse modo ordenado, o espaço de fluxos tem vocação a ser ordenador do espaço total, que lhe é facilitada pelo fato de a ele ser superposto. (SANTOS, 2000)

Tendo em vista que nas formações socioespaciais da América Latina "[...] o território, nações e povos conquistados em um longo processo de exploração, em favor de suas respectivas metrópoles e sob variantes que se alteravam de acordo com o contexto do capitalismo internacional" (VALENÇA, 2018, p. 34), a colonização impediu a conformação de territorialidades autônomas e subjulgou os territórios colonizados, alinhando, como dito, esses territórios na lógica do capitalismo mundial na condição de recursos.

As horizontalidades são

Zonas de contiguidade que formam extensões contínuas. Valemonos outra vez, do vocabulário de Françoix Perroux quando se referiu à existência de um "espaço banal" em oposição ao espaço econômico. O espaço banal seria o espaço de todos: empresas, instituições, pessoas; o espaço das vivências. (SANTOS, 2000)

Esse espaço banal, essa extensão continuada, em que os atores são considerados na sua contiguidade, são espaços que sustentam e explicam um conjunto de produções localizadas, interdependentes, dentro de uma área cujas características constituem, também, um fator de produção. (SANTOS, 2000)

As verticalidades aumentam em função da concentração cada vez maior dos centros mundiais de comando e do capital, e de sua necessidade de conexão com os pontos do território responsáveis pela execução das ordens e pela produção (TOLEDO JUNIOR, 2005). Já nas horizontalidades, "ainda que estejam presentes com diferentes níveis de técnicas, de capital e de organização, o princípio que permite a sobrevivência de cada uma é o da busca de certa integração no processo de ação" (SANTOS, 2000). Assim, ao impor relações verticais, e:

Ao subjugar os povos originários, Portugal e Espanha os inseriram em um complexo internacional até então por eles desconhecidos, como também 
impuseram relações de produção, formas organizativas, valores, religião, direito. Deste ato de força e de busca desenfreada por locupletar-se, constituiu-se um padrão civilizatório de traços intrínseco, com especificidades frente a outras realidades espaço-temporais. A sociedade colonial fundou seus pilares na submissão das civilizações indígenas predecessoras e em sua inserção dependente no circuito do capitalismo. (VALENÇA, 2018, p. 31)

A inserção desses povos e de seus territórios no capitalismo global, em condição de dependência, como destaca Daniel Valença na passagem acima, implica a colocação da América Latina nas dinâmicas da divisão internacional do trabalho, sendo reservada ao continente uma posição inferior, de dependência e pouco destaque, pois essa divisão do trabalho significa antes de mais nada que "[...] alguns países de especializaram em ganhar e outros em perder", sendo que "[...]nossa comarca no mundo [...] foi precoce: especializou-se em perder desde os remotos tempos" até os dias atuais (GALEANO, 2017, p. 17), de modo que:

\begin{abstract}
É a América Latina, a região das veias abertas. Do descobrimento aos nossos dias, tudo sempre se transformou em capital europeu ou, mais tarde, norte-americano, e como tal se acumulou e se acumula nos distantes centros do poder. Tudo: a terra, seus frutos e suas profundezas ricas em minerais, os homens e sua capacidade de trabalho e consumo, os recursos naturais e os recursos humanos. $O$ modo de produção e a estrutura de classes de cada lugar foram sucessivamente determinados, do exterior, por sua incorporação à engrenagem universal do capitalismo. Para cada um se atribuiu uma função, sempre em benefício do desenvolvimento da metrópole estrangeira do momento, e se tornou infinita a cadeia de sucessivas dependências, que têm muito mais do que dois elos e que, por certo, também compreende, dentro da América Latina, a opressão de países pequenos pelos maiores seus vizinhos [...] (GALEANO, 2017, p. 18)
\end{abstract}

Assim, resta evidente que a essencialidade da conquista e posterior colonização é territorial, de uso e exploração das riquezas desses lugares, que juntos conformam a América Latina, em território como recurso (SANTOS, 2006), por um lado, o dos invasores, e de resistência e luta pelo direito ao desenvolvimento territorial autêntico, próprio e em proveito do lugar mesmo, pelo lado dos oprimidos. E nesse estado de coisas, o modelo de gestão territorial, como resultado do direito e do sistema político, foram se inserindo como mecanismo legitimador e racionalizador de um tipo de uso do território que privilegia as verticalidades, ou ainda refletindo a síntese de uma luta de classes pelo território (MARX, ENGELS, 2008), daí advindo os modelos centralistas, unitários, federais etc., sempre a partir de uma amálgama de interesses e lutas políticas pelo controle do território, ou melhor, do uso deste.

As verticalidades são, pois, portadoras de uma ordem implacável, cuja convocação incessante a segui-la representa um convite ao estranhamento. Assim, quanto mais "modernizados" e penetrados por essa lógica, mais os espaços respectivos se tornam alienados. (SANTOS, 2000) 
Marcio Cataia (2013) ressalta que nos estudos sobre o território a categoria de análise é o território usado, antes que o pacto político-administrativo, que a este tem caráter instrumental, como face jurídica que racionaliza e normatiza o uso e os agentes hegemônicos nos usos do território, entre estes o modelo unitário centralista, o federalista, o regional, etc.; assim, antes que um debate técnico de cariz jurídico-político-administrativo, os estudos do território devem ser concebidos principalmente na seara do poder (ACHURY, 2018).

A Bolívia, por estar inserida nessa conjuntura latino-americana, também tem a sua conformação enquanto país entrecortado pela questão territorial, por disputas territoriais que vão dar cara, forma e conteúdo às regiões, às rivalidades entre elas pelo domínio do poder estatal e fomento de estratégias de usos territoriais ligados às diversas facções das elites, além da grande resistência indígena e dos mineiros no meio desse processo.

Desse modo, as "[...] questões indígenas, da terra e dos recursos naturais se entrecortaram por toda a história boliviana”. (VALENÇA, 2018, p. 32), com reflexos na formação político-territorial do País, talhando rivalidades entre terras baixas/altas, criollos/indígenas, leste/oeste, de modo que na Bolívia "[...] a clivagem entre a região ocidental e oriental, Andes e planície, indígenas e criollos, foi fortemente condicionada pela ausência de comunicações internas. Era como se existissem ao menos duas Bolívias." (SEBBEN, 2010, p. 58). É a forma como na Bolívia foram se criando as desigualdades e particularidades de seu território, moldando sua formação socioespacial.

A história político-territorial da Bolívia pode ser subdividida em colonial; republicano, composta pela fase caudilhista (1825-1880), outra mais propriamente dita constitucional-liberal (1880-1952-), pós-1952 e a neoliberal, de 1985-2005; (VALENÇA, 2018) e por fim o atual Estado Plurinacional da Bolívia, vigente desde a promulgação da Constituição de 2009, como simbiose de todas essas etapas do Estado boliviano (CUNHA FILHO, 2018). Em todas etapas da gênese da formação socioespacial da Bolívia foi se constituindo um forte traço vertical no uso do território, em que a institucionalidade estatal e o direito deste proveniente acudia essa tendência, se contrapondo às horizontalidades que resistiam por serem a maior parte da população e do território, onde por vezes ocorriam alianças entre os donos do poder e os oprimidos de toda sorte, notadamente indígenas e camponeses, mas sempre em condições de submissão. Ao longo dessa história boliviana, as desigualdades territoriais foram sendo sucessivamente reforçadas.

No período colonial, após a Coroa Espanhola obter garantias jurídicas perante à ordem internacional de então, por bulas papais, iniciou-se a etapa da colonização propriamente dita e a ressignificação e exploração daqueles territórios. A princípio, a exploração das riquezas que o espaço geográfico representava aos espanhóis se deu num caráter privado. Incapaz de prover por si mesma vultosos investimentos que a empreitada requeria, atuou a Corte Espanhola mediante parceria com aventureiros, mediante capitulações de natureza jurídica privada, em que o Poder Real concedia o direito de exploração sobre os lugares desbravados, embora sob batuta oficial (CAPDEQUÍ, 1993).

Posteriormente, o Poder Real Espanhol empreende uma retomada do processo de ordenação territorial, transferindo o protagonismo da seara privada para a pública, fortalecendo o controle do Estado Espanhol sobre as Colônias. A 
medida é implementada ante o temor da alta cúpula real de perder o controle efetivo dos novos territórios ante o crescente poder dos primeiros expedicionários.

Compôs esse conjunto de medidas visando maior controle real sobre os novos territórios, mediante o desenvolvimento de uma burocracia estatal mais sólida, sob um modelo de ordenação territorial de boa parte do período colonial que compartimentava político-administrativamente o território em Vice-Reinados, Audiências e Municípios (CAPDEQUÍ, 1993). O objetivo era centralizar a administração sob mãos consideradas de confiança, aumentando significativamente o controle sobre os territórios, em detrimento da influência dos criollos, daí datando, por exemplo, a tradição da América Hispânica pelo modelo unitário de organização estatal após a independência.

A essa redefinição político-administrativa do território também se sobrevém a implementação de um modelo produtivo mais organizado, de agricultura e mineração voltado à demanda externa e interesses econômicos hegemônicos a nível local. Superada a etapa da pilhagem, os conquistadores "[...] organizaram forças produtivas em geral voltadas à mineração, agricultura e extrativismo". (VALENÇA, 2018, p. 35).

A implementação dessas atividades também variava de acordo com as particularidades locais, isto é, do nível desenvolvimento e organização dos lugares e suas potencialidades, um exemplo claro de como o espaço geográfico funciona como forma-conteúdo nos projetos de uso do território. De um modo geral, as sociedades autóctones eram de cunho familiar e se organizavam em comunidades sem a presença do Estado, aqui em sentido lato, e em propriedades comunitárias denominadas Ayllus (VALENÇA, 2018). Nessas situações, os invasores davam prioridades a atividades atreladas à agricultura.

No caso de sociedades mais complexas, ocorria uma apropriação e ressignificação dos papeis sociais existentes previamente nessas comunidades, de modo a melhor atender aos auspícios espanhóis, num processo de hibridação, como foi o caso dos Incas. Essa comunidade foi uma das mais imponentes sociedades précolombinas, organizada sob a propriedade coletiva da terra, a divisão social do trabalho, um Estado teocrático e direcionamento dos excedentes ao Estado, que o redistribuía, em grande parte, para o proveito social e foi cooptada e adaptada aos interesses hispânicos. (VALENÇA, 2018), assim "[...] aproveitando se tratar de povos que respeitavam hierarquias sociais estabelecidas [...] os espanhóis utilizaram de mecanismos que reproduzissem um domínio, agora sob o comando da metrópole europeia" (LEONEL JÚNIOR, 2018, p. 13), de modo que as

\begin{abstract}
Relações de produção hierárquicas existentes desde a era pré-colombina foram ressignificadas, a partir da adequação dos institutos das encomiendas e da mita, bem como das experiências do feudalismo espanhol. A relação de produção servil, portanto, fora transladada para a colônia, de maneira adaptada às condições de reprodução social preexistentes à chegada ibérica. A servidão individual, típica do feudalismo, aqui se manifestou coletiva, comunitária. Sua ressignificação implicava em outro padrão de apropriação do excedente do trabalho, agora voltado à acumulação mercantil e não mais reprodução social da comunidade. (VALENÇA, 2018, p. 42)
\end{abstract}

Portanto, não apenas houve uma ressignificação da estrutura produtiva existentes nas sociedades pré-colombinas, como também do arquétipo político. 
Sucedeu após a consolidação da conquista/colonização uma relação política entre o poder Real e os indígenas, onde as autoridades indígenas de outrora eram mantidas nessa condição privilegiada, mas agora como intermediário, o elo entre o indígena e o colonial, assim:

\begin{abstract}
Com o Império Inca derrotado, a então nobreza inca, que se alia aos espanhóis, passa a se constituir como engrenagem fundamental para a reprodução da lógica colonial europeia sob uma roupagem própria, uma vez que exercida pelos próprios indígenas andinos. A monarquia espanhola criou a figura dos "caciques". Indígenas passaram a compor a nobreza dentro da colônia, submetidos à metrópole, os quais cobravam tributos de alguma unidade sócio-territorial, que presidiam. Literalmente, um processo de reprodução da colonialidade do poder. Esse mecanismo dominador e reprodutor do colonialismo tinha, além do cacique, a figura do corregedor que era responsável pelo acompanhamento do trabalho dos caciques, auxiliando a coroa. (LEONEL JÚNIOR, 2018, p. 13)
\end{abstract}

Essa fase da história boliviana é marcada pela coexistência entre os dois mundos, o projeto colonial de capitalismo mercantilista e os povos originários, ainda que, obviamente, de submissão dos segundos aos interesses do primeiro, marcando uma tolerância interesseira, na medida em que cumprissem com suas obrigações tributárias-econômicas perante à Coroa, desfrutariam de relativa e legal autonomia sobre seus territórios e manutenção de suas territorialidades. (CUNHA FILHO, 2018) (VALENÇA, 2018), o que ficou conhecido como pacto de reciprocidade (CUNHA FILHO, 2018). Segundo esse autor, o então vice-rei do Peru, Francisco de Toledo, que tinha a audiência de Charcas sob sua autoridade, o que corresponde ao território da atual Bolívia:

[...]buscou concentrar as comunidades indígenas que viviam espalhadas por grandes territórios em reduções de geografia semelhante ao urbanismo castelhano de então. Como forma de diminuir algo do poder dos caciques, criou uma série dos postos civis análogos aos existentes na Espanha, como prefeitos e corregedores, cujas autoridades se sobrepunham ao poder soberano dos caciques sobre as comunidades. Mas para garantir o controle sobre essas mesmas comunidades e sua aquiescência à extração de tributos e trabalho necessários para a colônia, o vice-rei manteve em grande medida o papel dos caciques como intermediários entre os dois mundos e com a manutenção de altos graus de autonomia interna às comunidades conquanto seguissem cumprindo com suas obrigações coloniais tributárias e de fornecimento de mão de obras às minas. (CUNHA FILHO, 2018, p. 37-38).

A sociedade colonial se consubstanciou desde uma estratificação étnicoracional, na qual os espanhóis ocupavam os cargos e papeis políticos e sociais de maior relevância, seguidos pelos criollos, que eram secundarizados na política e tinha protagonismo econômico e na base da pirâmide social os indígenas e os mestiços (CUNHA FLHO, 2018), (VALENÇA, 2018). Do ponto de vista políticoadministrativo, data desta época a tendência da Bolívia republicana em calcar seu modelo de gestão territorial no centralismo unitário, visto que o poder Real instituiu um sistema altamente concentrado, complexo, repleto de burocracias, e até mesmo confuso como estratégia de manter sob seu jugo o controle as Colônias, prática essa que irá persistir nas diversas constituições do país, a despeito dos reclamos por autonomia, tais como a Guerra Federal e outros episódios. 
Após a independência, em 1825, a Bolívia se forma como país a contragosto do Peru e da Argentina, que gostariam de ter essa porção territorial incorporada aos seus respectivos domínios, e é batizada em homenagem ao Libertador Bolívar (CUNHA, 2018). Naquela data, a Bolívia inicia sua trajetória no constitucionalismoliberal, bem como no modelo estatal unitário de organização político-territorial. Como é cediço, na América Latina, após a independência, o rompimento oficial do jugo colonial, os Países recém constituídos buscaram inspirações nas exitosas revoluções liberais da França e principalmente dos Estados Unidos na tarefa de construir as novas bases sociais, políticas, institucionais e jurídicas dessas nações, em suma, no anseio de modernizar as bases materiais desses Países.

A Bolívia, assim como seus vizinhos, construiu uma estrutura estatal para atender aos interesses de suas elites locais, mas com a particularidade de não ter maiores preocupações em aprofundar sua presença institucionalizada e ideológica por toda sua dimensão territorial, nem com a diversidade de territorialidades existentes, principalmente com relação aos povos originários, dai Zavaleta (2013, apud Valença, 2018) pugnar que o Estado boliviano sempre foi um Estado aparente, que existia somente na exata medida dos interesses econômicos de elites regionais, pois

Tendo em vista o modelo econômico e político constituído durante o período colonial e herdado no século XIX, que implicava "ilhas" de geração de riqueza e monopólio político-econômico por poucos grupos urbanos e latifundiários, mostrava-se desinteressante a presença estatal em todo o território nacional. O Estado existia na exata medida - e delimitação espaço-temporal - em que possibilitasse a acumulação de capital por parte de suas elites dirigentes. [...] este não tinha o condão nem o buscava - de condensar a totalidade da sociedade, ou seja, irradiarse por seu território impondo os diversos hábitos, culturas, formas de organização política, coercitividade, de suas classes dirigentes. O Estado não lograva articular a territorialidade estatal, somente fragmentos espalhados e dispersos, que tivessem alguma possibilidade de geração de riqueza. (VALENÇA, 2018, p. 57) (grifos originais)

Essa característica do Estado, por conseguinte, era muito dependente dos ciclos de pujança econômica do País e de sua localização geográfica. O que implicava, na prática, que a cada derrocada e ascensão de uma determinada atividade econômica como motor do desenvolvimento das forças produtivas bolivianas, o poder de influência sobre esse Estado migrava juntamente com o deslocamento dessa capacidade econômica regional. O Estado aparente, assim, sempre foi objetivo de disputa das elites, cuja captura significava deter meios político-econômicos de priorizar e realizar ajustes espaciais de modo a fomentar ou viabilizar suas atividades, em prejuízo quase que generalizado do restante do País. (CUNHA FILHO, 2018).

Além disso, o Estado boliviano se forma numa condição de contrastes entre o idealizado e real. Organiza-se sob a herança colonial da centralização do poder político dos tempos de colônia, razão pela qual adota como modelo de ordenação territorial o Estado Unitário de inspiração francesa (PAVANI, ACHURY, 2017), bem como do modelo norte-americano o presidencialismo e o sistema de freios e contrapesos (GARGARELLA, 2016), tudo isso sob um manto ideológico que se quer 
liberal, cultuando, ao menos no discurso oficial e jurídico, os valores da revolução francesa de liberdade, igualdade e fraternidade. Por outro lado, tinha o interesse de manter as condições materiais de reprodução da sociedade colonial, altamente excludente e racista:

\begin{abstract}
A Bolívia se iniciou como república herdando a estrutura social colonial. A distribuição de terras, a estratificação social, o regime de tributos e, inclusive, parte da administração pública e do pessoal encarregado de executá-la não sofrendo variações substanciais, deixando de pé o conjunto de sistemas de divisão de classes, poderes, instituições e pessoal hierárquico formado durante as distintas etapas do regime colonial. (LINERA, 2010a, p. 165).
\end{abstract}

A presença limitada e desigual do Estado no território nacional, obviamente traria consequências para a formação socioespacial do país. Por um lado, o dos indígenas, colaborou em grande medida para a conservação de sua cultura, organização política e territorial, apesar de estar oficialmente submetido ao um Estado republicano, cuja ideologia liberal pregava a universalidade e a homogeneidade.

Por outro, a disputa entre as elites pelo poder político do Estado fez do regime político boliviano algo muito instável, com sucessivos golpes para acesso ao poder, muito embora sempre se valessem dos símbolos liberais para legitimação desses governos, tais como a presença de constituições como ferramenta de organização e legitimação da ação estatal. Esse Estado aparente também resultou em perdas de porções territoriais em confrontos bélicos com seus vizinhos, pois por sua precária tecnificação do território, bem como a rarefeita coesão de uma nacionalidade, uma identidade boliviana, colocou-lhe em desvantagem logística e de engajamento social nesses conflitos, concorrendo para o ocaso (CUNHA FILHO, 2018).

A opção política de construir um Estado aparente, de presença seletiva, conjugada com fatores físicos que já tornavam hercúlea a integração do País, de ocidente ao oriente, do altiplano andino às terras baixas, resultou numa diferenciação espacial que centrava suas atenções na região andina, motivo pelo qual lutavam por uma sociedade andinocêntrica, e na desconexão com o resto do território, em especial as terras baixas, os departamentos da medialuna (figura 1), tanto no que diz respeito às elites regionais, quanto para os indígenas, sendo esse modelo de Estado centralista apontado como uma das causas do isolamento entre as partes do País e o nascimento de identidades territoriais regionais, pois esta é uma:

[...] de las grandes fracturas históricas [que] se produce entre el Estado y las regiones. Como resultado de la dominación colonial que sólo buscaba la extracción y expatriación del excedente económico, el Estado boliviano nació con una geografía de enclave, centrada en los centros mineros de la parte andina del país. El resto de las regiones, cuando estaban exploradas, quedaron débilmente integradas al territorio nacional y relegadas a un rol de periferia. En esas regiones se desarrolló un imaginario de abandono por parte del Estado andinocentrado que, de manera recurrente, en momentos de especial convulsión política o económica se he en desafección u hostilidad. (GALVÁN, 2009, p. 124). 


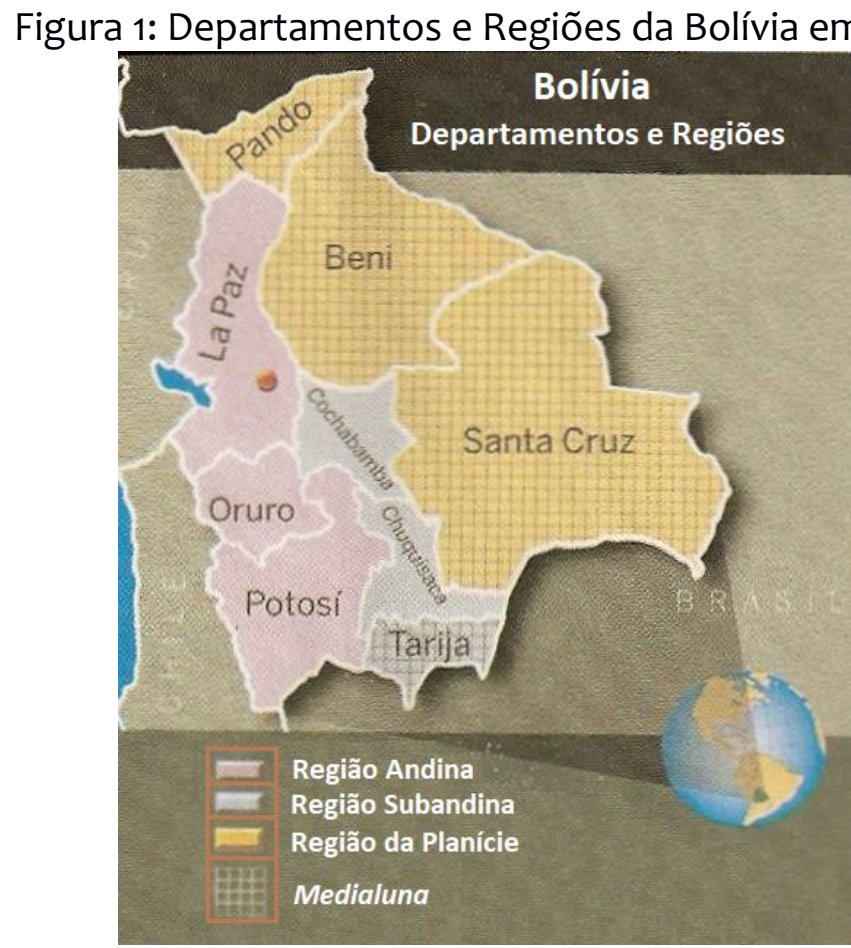

Fonte: Adaptado de GUALLUP et al, 2007

Essa situação perdurou quase que absolutamente até a Revolução de 1952, testemunhando-se modificações na vigência de um Estado mais nacionalista que se forjou após este episódio histórico. Uma das medidas que foram implementadas nesse período foi uma marcha ao oriente, sob a batuta de um plano de desenvolvimento agroexportador denominado Plano Bohan a partir de 1953, que resultou em investimentos massivos na região, em especial em Santa Cruz, que passou a condição de polo exportador, com alta densidade técnico-normativa, de modo que para, Galván (2010), com base em Romero (2006, p. 40), isto "[...] tuvo su traslación política: Un de modernidade subalterna, comandado por una elite agroexportadora y financeira dependiente y fuertemente subvencionada, consolidó una estrutura social altamente polarizada y rígida, y fomento sentimentos regionalistas." (2010, p. 88-89).

Foi nesse período, por exemplo, que foi construída a "[...]primeira rodovia asfaltada entre Cochabamba e Santa Cruz, que além de facilitar o acesso ao oriente, deflagrou o intenso crescimento de Santa Cruz[...]" (DINIZ, CAMPOLINA, 2006, p. 520), compondo um amplo rol de obras de infraestrutura com o fim precípuo de dar fluidez ao território, ações típicas de ajustes espaciais exigidas pelo capitalismo (HARVEY, 2018).

Entretanto, apesar do impulso econômico modernizador, e da grande relevância que o Estado pós-1952 teve na construção (ou ao menos esforço) de um Estado verdadeiramente nacional, no plano político-territorial, o período não representou grandes mudanças no que tange à descentralização/autonomia, visto que em "[...] realidade esta intención [de marcha ao oriente, então isolado] se enmarcaba en una visión altamente centralista y de consolidación de la ideologia integracionista" (ZEGADA, 2012, p. 92). E segundo esta autora, desde então nessa região, formou-se uma pauta de reivindicações do regional ante o nacional por mais 
autonomia, receitas para os departamentos orientais e, embora tenha restado latente por grande período, irrompeu-se já nas décadas de 1980 e 1990 do século $X X$, sob a hegemonia neoliberal.

O neoliberalismo, trouxe aos temas de primeira ordem ventos de reivindicação territorial no país. No caso da Bolívia, em linhas gerais, produziu um prontuário comumente observado nos demais Países, especialmente latinoamericanos, apesar de suas particularidades locais, que fizeram sua experiência única, ao mesmo tempo que consolidava o projeto neoliberal, possibilitava a semeadura das sementes da revolução que irromperia no início dos anos 2000, 0 conhecido período rebelde 2000-2005 (LEONEL JUNIOR, 2018).

De tal modo, durante a hegemonia neoliberal, se implementaram novas verticalidades em proveito de agentes transnacionais; ressignificação do Estado, que passou a eminente condição de fiador do projeto neoliberal, com as consequências disso decorrentes, tais como desregulação, desnacionalização de políticas de Estado e privatização da produção de normas, ou seja, a regulação corporativa do território (ANTAS JR, 2005), reestruturação das escalas internas de poder, de organização político-administrativa (SASSEN, 2015), privatização da política e da cidadania (BELLO, 2018), desnacionalização de empresas e recursos estatais/nacionais, liberalização do mercado, e a centralidade econômica como fim último da ação do Estado, com o consequente ataque aos direitos sociais (DARDOT, LAVAL, 2016).

Concomitantemente, do lado subalterno, essas ações resultaram por aprofundar as demandas territoriais existentes no decorrer da história do País, além de criar condições para o futuro levante popular, num grande bloco subalterno, composto por indígenas, campesinos e mineiros, no início dos anos 2000. As medidas político-administrativas levadas a cabo pelo Estado neoliberal boliviano, que visavam o arrefecimento das exigências territoriais feitas pelos grupos sociais marginalizados, (tanto os povos originários, quanto os departamentos do oriente de modo geral), e, de tal modo, propiciar um ambiente político propício para a propagação da racionalidade neoliberal, restaram por permitir maior engajamento e organização desses grupos no processo de se contrapor aos efeitos perversos advindos da experiência boliviana na globalização, fortemente marcado pela deterioração das condições de vida e do emprego.

Oficialmente, a hegemonia neoliberal na Bolívia perdurou por duas décadas, e se iniciou com o êxito eleitoral de Victor Paz Estenssoro nas eleições presidenciais de 1985, e teve sua derrocada em 2005, ano em que Evo Morales ascende ao poder pelo Movimiento Al Socialismo (MAS), quando levou consigo, as esperanças e anseios dos subalternos para uma refundação do Estado boliviano por meio de uma assembleia constituinte e se consolida como porta-voz das reivindicações que marcaram o período rebelde 2000-2005, em contestação aos efeitos deletérios do neoliberalismo, e entra para a história política do País ao ser o primeiro indígena a ocupar o cargo de chefe maior da nação.

Na Bolívia, o movimento sindical das forças sociais operárias ganha fôlego posteriormente ao fracasso nacional na Guerra do Chaco (1932-1935), numa crescente até a Revolução Nacional de 1952, quando também é criada a Central Obreira Boliviana (COB). Teve grande importância até o ano de 1964, quando esse segmento assume a condição de principal ator social de mobilização popular, mas 
se fragilizou quando um golpe militar levou ao poder forças políticas que recrudesceram o combate a essas forças insurgentes (1964-1982).

Nos anos posteriores, a intensa construção de verticalidades no território boliviano, proporcionadas a partir de globalismos localizados, pode ser considerada a principal característica desse momento histórico (1985-2005), construído por uma elite empresarial sobre os escombros, sistematicamente produzido, do principal ator político subalterno da época, os mineiros/obreiros, como bem preconiza Linera (2010a), ao ressaltar que:

Foi sobre essa desagregação do sindicalismo ligado ao Estado que se
consolidou um bloco social composto por fraçães empresariais vinculadas
ao mercado mundial, partidos políticos, investidores estrangeiros e
organismos internacionais de regulação que ocuparam o cenário
dominante da definição de políticas públicas. Durante quinze anos, a
tomada de decisões na gestão pública (reformas estruturais de primeira e
segunda geração, privatizações, descentralização, abertura de fronteiras,
legislação econômica, reforma educacional etc.) teve como único sujeito
de decisão e iniciativa essas forças sociais que reconfiguraram a
organização econômica e social do país sob promessas de modernização
e globalização. (2010a, p. 282).

Entretanto, não foi somente no plano econômico, financeiro e laboral que se encetaram mudanças de cariz neoliberal da globalização. Como pontuam Sassen (2010), Baggio (2014) e Bello (2018), a globalização requer, respectivamente, seus próprios arquétipos de geografia política e cidadania. Essas autoras destacam que o modelo político dos Estados inseridos na Globalização busca esfacelar qualquer desenho institucional de Estado social, usando a geografia política como uma ferramenta nesse sentido.

A estratégia consiste em concentrar o poder político no poder central e descentralizar todas as demais atribuições de cunho social ou de serviço público aos entes sub-nacionais, numa estratégia para blindar a sala das máquinas de maior poder e responsáveis pela implantação da racionalidade hegemônica de questionamento de índole social, canalizando as insatisfações populares para os entes sub-nacionais.

De tal modo, na Bolívia, houve um conjunto de reformas de cunho políticoadministrativo, mas a de maior relevância foi a Lei de Participação Popular, que tinha o papel de neutralizar os reclamos por descentralização, promovendo uma descentralização administrativa, de modo que:

\footnotetext{
A Lei de Participação Popular que descentralizou a administração estatal por meio dos municípios, somada à maior integração das elites regionais, especialmente cruceñas, e à estrutura do Estado centralista por meio dos partidos MNR, MIR e ADN, encerrou o ímpeto descentralizador dos anos 1980 e levou as elites empresariais cruceñas a ocupar posições de poder fundamentais na estrutura estatal que acompanhou as reformas de livre mercado de todo o período neoliberal. (LINERA, 2010a, p. 310).
}

A Lei de Participação Popular (LPP) de 1994 logrou ordenar política e administrativamente o território, resultando na criação de mais de 300 municípios, um feito inédito num país marcado pela ausência do Estado no seu interior e de demarcação político- 
territorial. Também representou um grande avanço em relação à luta dos povos indígenas por território e autogoverno, na medida em que a LPP também os contemplava, pois a "[...] LPP estabelecia a possibilidade de criação de distritos municipais indígenas com autoridades próprias no interior dos municípios e estabelecia a possibilidade de criação de Organizações Territoriais de Base (OTBs) com poderes de supervisão dos orçamentos municipais". (CUNHA FILHO, 2018, P. 114).

Segundo o mesmo autor, esses avanços foram complementados pela criação das Terras Comunitárias de Origem, em 1996, com um projeto de reforma agrária. Tudo isso num panorama constitucional em que pela primeira vez se reconheceu o caráter multiétnico do país, em reforma à constituição em 1994, no Governo de Gonzalo Sánchez de Lozada (1993-1997), que tinha como vice-presidente o aimará Victor Hugo Cardenas.

A medida, entretanto, conforme antecipado, era cercada de contradições, visto querer mais do que explicitamente dizia. Se por um lado promovia a ordenação territorial do país, atendendo a demandas de repactuação, mediante a descentralização e fomentando a participação popular nos níveis sub-nacionais, por outro lado alimentava uma racionalidade indigenista e buscava também fortalecer e garantir andamento estável ao projeto neoliberal de uso do território, pois:

[...] o objetivo do governo com a municipalização era, por um lado, responder às demandas regionais de descentralização (sobretudo do Oriente Boliviano) e, ao mesmo tempo, entregar aos municípios a responsabilidade pelo fornecimento de serviços até então eram de responsabilidade do governo central, o que ao mesmo tempo favorecia os objetivos da NPE de afastar protestos em torno das políticas nacionais e dirigí-las a conflitos localizados nos municípios[...] (CUNHA FILHO, 2018, p. 114).

As contradições entre o dito e o ocultado aumentavam na medida em que os recursos transferidos aos municípios para a gestão e implementação dos serviços que agora eram de sua responsabilidade eram insuficientes. Outro ponto que arrefecia o pretenso caráter progressista da medida, em especial em relação aos povos originários, apesar do ineditismo, era a execução, ou implementação, dessas novas unidades sub-nacionais, qual estavam ladeados de um tecnicismo propriamente neoliberal, com grandes exigências, ritos liberais e um complexo burocrático, que, na prática, inviabilizava a emancipação territorial desses povos, evidenciando um profundo e estrutural racismo, de modo que:

[...]muitas das OTBs de cunho indígena acabavam tratadas com condescendência e paternalismo, quando não completamente ignoradas em atitudes quase abertamente racistas, nas reuniões decisórias de que participavam por não manejar com desenvoltura os conhecimentos técnicos requeridos. Ademais, muitas dessas detalhadas regras burocráticas prescritas ne LPP acabavam em seu pretenso universalismo excluindo a determinados grupos indígenas, sobretudo em regiões de grande diversidade étnica. (CUNHA FILHO, 2018, p. 115).

Isso dito, fica evidenciando o ajuste neoliberal no territórioda Bolívia e de como esse processo, ao menos na sua intencionalidade, muito se aproxima do sublinhado por Baggio (2014), ao vivenciado pela federação estadunidense, na passagem de um Estado Social Keynesiano para um propriamente neoliberal. O decurso do tempo não trouxe ao povo boliviano as benesses prometidas pela globalização, conhecendo esse país andino tão somente a sua face perversa, parafraseando Milton Santos (2000). O desemprego, a ressignificação da atuação do Estado como guardião do mercado e interesses transnacionais, a neoliberalização do mercado, do território e das dinâmicas sociais, 
calcadas em verticalidades, e a crescente deterioração e depauperação da vida dos trabalhadores, indígenas, camponeses e dos mais subalternos foram os traços característicos desse período. Sue lamamoto sublinha com precisão o que representou, para cada um deles, a hegemonia da globalização:

\begin{abstract}
Para os operários, significou a morte do pouco "capitalismo de Estado" que havia na Bolívia, o fim simbólico de sua grande expressão organizativa durante o século XX, a COB. Para os camponeses, significou a deterioração dos preços de seus produtos e o avanço de políticas que afetavam a economia agrária; mas, politicamente, também significou a subordinação ao imperialismo norte-americano com relação às políticas a antidrogas. Para indígenas, deixou os seus territórios ainda mais vulneráveis a forças externas agressivas (madeireiras, petroleiras, privatização da água, latifundiários); mas também representou um aparato estatal externo invasivo, incapaz de compreender e incorporar indígena. (IAMAMOTO, 2011, p. 60)
\end{abstract}

E como é próprio do processo da globalização, a seletividade espacial para um desenvolvimento predatório, a Bolívia viveu no período de hegemonia neoliberal a fragmentação de seu território, quando aqueles lugares de predileção do capitalismo global recebiam investimentos alinhados aos seus interesses em detrimento do desenvolvimento nacional e da integração territorial, num profundo processo de vertizalização na produção e uso do território, concebido mais como recurso que abrigo, (SANTOS, 2000), produzindo-se, como resultado, o agravamento das já severas desigualdades territoriais internas que assolam o País desde praticamente sua fundação. O Estado e o Direito atuaram como sócios nesse projeto, adaptando as estruturas internas para melhor acomodar esse impulso globalizante e neoliberal que se impregnava na política socioespacial naquele período histórico.

Como consequência dessa acumulação histórica de eventos incorporados ao território, com impulsos hegemônicos verticais (colonialismo, neocolonialismo, colonialismo interno, globalização), é que a Bolívia vira do século XX ao XXI, segundo Galván (2009), tendo como déficits territoriais, além da já mencionada estrutura andinocêntrica e natureza centralista oligárquica, fraturas entre Estado e Sociedade, enfatizando-se a desarticulação entre o Estado e o povos indígenas; e daquele com as regiões, que como já mencionado, sentiam-se alijadas do processo nacional e forjaram identidades regionais próprias.

Sem embargo, a conjugação do aprofundamento das verticalidades decorrente da globalização e os deletérios impactos desta advindos elevou a tensão social a um insuportável nível, dando margem para uma eclosão social, que veio a ocorrer nos idos dos anos 2000 com as conhecidas Guerra da Água (2000) e do Gás (2003), cuja pressão popular desaguou no ocaso final da estrutura de poder que dominava o Estado, que já vinha agonizando, e a conformação de uma hegemonia popular composta pelos grupos oprimidos, que ficou conhecida como IndígenaPopular e tornou possível a vitória eleitoral de Evo Morales em 2005. Como plano político, trouxe consigo a agenda de outubro (de autoria dessa nova hegemonia) e que tinha como ferramenta para a construção de uma solução aos problemas sociais de então a convocação de uma assembleia constitiuinte.

A assembleia constituinte foi convocada, e como ressalta Dalmau (2011), ao final de um longo e belicoso processo constituinte foi instituído o inédito Estado 
Plurinacional da Bolívia, com o objetivo de iniciar a transição de um estado aparente a um integral e plurinacional (LINERA, 2010b), e comprometido precipuamente com a redução dessas desigualdades no uso do território.

\section{A constituição democrática de 2009 e o reforço das horizontalidades}

Após uma histórica acumulação de reinvindicações em torno do uso e gestão do território de modo mais democrático, inclusivo, é com o inaudito e brutal processo de construção de verticalidades imposto pela globalização, e a precarização da vida social desta derivada, que eclode um levante popular a exigir mudanças socioespaciais, que se tornou possível com a conformação de uma inédita hegemonia subalterna, entre indígenas, camponeses e mineiros, ainda que com maior protagonismo indígena, e que viria ser denominada de hegemonia indígena-popular. A pauta reivindicatória, a agenda de outubro, era composta principalmente pela descolonização do Estado, nacionalização dos recursos naturais e a convocação de uma assembleia constituinte (GALVÁN, 2009) (IAMAMOTO, 2011). O êxito eleitoral de Evo Morales, pelo MAS, em 2005, numa inédita eleição em primeiro turno, demonstram o grau de insatisfação e o desejo de mudança da população.

A futura constituinte, assim, tinha como missão iniciar um processo de correção dessas fissuras territoriais, formular um Estado integral (LINERA, 2010b) em oposição ao histórico Estado aparente, como ressalta este autor, num contexto profundamente polarizado, conflituoso. A opção de cambio se deu via democrática, do constitucionalismo democrático, diferentemente da impregnada cultura de golpes de Estado, constituindo-se um claro uso contra-hegemônico de instrumentos hegemônicos para pavimentar a emancipação, daí Rubén Martinez Dalmau e Roberto Viciano Pastor (2012) pugnem pela existência de um nuevo constitucionalismo latino-americano, conformado pelas experiências de Colômbia (1991), Venezuela (1999), Equador (2008) e a Bolívia (2009), em contraposição à tradição nominalista do constitucionalismo na região, visto que agora levado a termo pelo povo e em prol de seus interesses, rompendo a secular lógicas de constitucionalismo dirigidos pelas elites, na construção de um Estado Constitucional.

Nessa perspectiva teórica, a constituição é a consolidação da manifestação soberana do poder constituinte originário, o povo, por isso uma constituição democrática, à qual os poderes constituídos devem subordinação e obediência, somente encontrando os poderes constituídos legitimidade e constitucionalidade de seus atos na exata medida em que guardam conformidade com a vontade seu criador, o povo, plasmada no texto constitucional, fundando, assim, um Estado Constitucional, de supremacia constitucional. A constituinte se daria num panorama de intensa disputa territorial, haja vista a existência de dois projetos, um capitaneado pela nova hegemonia que se formava, comprometida com a emancipação social, descolonização, construção de um Estado integral (LINERA, 2010b), e redução das desigualdades espaciais, especialmente com as demandas indígenas e campesinas; e outro de viés mais conservador, da região oriental, dos departamentos da meia lua, sob a liderança de Santa Cruz de la Sierra, pela 
manutenção do status quo macroeconômico, reclamando, para tanto, um Estado autonômico, descentralizado. (GALVÁN, 2009) (IAMAMOTO, 2011).

Os departamentos do Oriente, foram os mais beneficiados pela fragmentação territorial ocasionada pela globalização, aprofundando sua vocação agroexportadora iniciada nos anos de 1950, como visto, e sendo o destinatário de grandes investimentos estrangeiros, alcançando, assim, certo grau de desenvolvimento tecnológico, ainda que na condição de dependência, de subdesenvolvimento periférico, e uma vez perdido protagonismo político nacional, fez do regionalismo e da pauta autonômica sua bandeira de reivindicação na tentativa de manter seu descolamento em relação ao nacional e manutenção das dinâmicas territoriais próprias da globalização neoliberal, sem desconsiderar ainda o ímpeto separatista nutrido por parte de seus partidários.

Foi nessa ambiência que se sucedeu o mais democrático processo constituinte da história da Bolívia, que pela primeira vez incluiu e foi conduzido pelas forças populares. (DALMAU 2011). Entretanto, a despeito disso, não sem lutas e adversidades, sendo o mais longo, conflituoso, amplo e heterogêneo processo constituinte do que se denota Novo Constitucionalismo Latino-Americano. E ainda teve que contar com impropriedades teóricas a respeito da convocação e execução do poder constituinte originário, ora acordo, ora ataques dos poderes construídos e das elites política e econômica que se viam depostos dessa condição, que, no somatório, de alguma forma limitou seu caráter originário, apesar da inquestionável vocação popular e emancipadora, conforme pontua este autor.

Sem a pretensão de exaurir o tema, o principal incidente formal foi a limitação da ação do poder constituinte originário pelos poderes constituídos, ao se editar uma Lei que iria disciplinar o processo de feitura, a assembleia constituinte, da nova constituição, a Lei $n^{\circ} 3364$, conhecida como Lei Especial de Convocatória, que impôs um quórum de $2 / 3$ dos constituintes para a aprovação do texto constitucional, garantindo às forças reacionárias, em especial do oriente, um poder de barganha, de resistência, haja vista não alcançar o MAS e o seu bloco político cadeiras nesse percentual (DALMAU, 2011) (LEONEL JUNIOR, 2018), destaque também para a exigência dos poderes constituídos para uma consulta prévia e vinculante sobre as autonomias.

No âmbito dos debates sobre a redação da nova constituição, as forças do oriente seguiram combativas na defesa de autonomias como estratégia de manter 0 controle sobre os territórios de sua alçada, apostando também na existência de um Estado Unitário como dique de contenção ao ímpeto descolonial das forças indígenas, especialmente andinas, e dos mineiros, visto pelo oriente como peso, sinônimo de atraso e subdesenvolvimento. O oposto, com adaptações, também é verdadeiro. A hegemonia indígena-popular enxergava nas autonomias, em especial na Indígena-Originária-Campesina, uma estratégia fulcral na descolonização do Estado, e a existência de um governo central, no âmbito de um Estado Unitário, mas descentralizado e com autonomias, uma maneira de mitigar o ímpeto reacionário dessas forças antagonistas, assim Estado Unitário, Descentralizado e com Autonomias, assim como os ideais de plurinacionalidades eram espaços disputados por projetos de país bastante discrepantes, podendo coincidir no significante, mas divergindo cabalmente quanto ao conteúdo (IAMAMOTO, 2011). 
A plurinacionalidade, por exemplo, era vista pelo povos originários como o reconhecimento das nações preexistentes, precolombinas, para além dos paradigmas de multiculturalismo, pluriétinico, para incluir a implementação de uma geografia política verdadeiramente plurinacional, com instituições dentro e reconhecidas pelo Estado, com autogoverno, livre determinação territorial, no marco de um Estado Unitário, numa espécie de aplicação do princípio da autodeterminação intraEstado, marcadamente intercultural (GALVÁN, 2010) (IAMAMOTO, 2011). Por outro lado, o projeto proposto pela oposição ao governo, pugnava uma plurinacionalidade como um reconhecimento da diversidade do país, mas sem grandes impactos institucionais.

Sem embargo esses e tantos outros obstáculos enfrentados por esse processo de refundação do Estado, a constituição foi enfim promulgada. Mas não sem antes um acordo com os poderes constituídos, uma vez já tendo ela sido aprovada pela Assembleia Constituinte, que em parte mutilou a vontade do poder constituinte originário. No dia 25 de janeiro de 2009 foi aprovada em referendum por $61,43 \%$ dos votos. Para Dalmau (2011), a aprovação do texto constitucional no referendum como que de alguma forma corrigiu essa carência de legitimidade do acordo que deu a última versão da constituição.

Entretanto, ainda que com as dificuldades próprias de qualquer processo revolucionário, que se pretende demolir as velhas estruturas, e as limitações por essas impostas e os erros que porventura possam ter ocorrido, como bem pontua Dalmau (2011), a constituição deve ser celebrada como uma conquista do povo boliviano como um processo de transição e emancipação que vai se aperfeiçoando a partir da vontade do povo. Além disso, restou por incorporar as reivindicações que Ihe deu origem, sendo marcada por grandes inovações institucionais e principalmente em seus dispositivos territoriais, amplo catálogo de direitos, forte presença do Estado como guia desse processo de transição, constitucionalização das cosmovisões indígenas, de relação com a natureza, o bien vivir, etc.

Assim, se constitui o Estado Plurinacional da Bolívia, que segundo dispõe o artigo $1^{\circ}$ de sua Constituição, é um “Estado Unitario Social de Derecho Plurinacional Comunitario, libre, independiente, soberano, democrático, intercultural, descentralizado y con autonomias" e que "[...]se funda en la pluralidad y el pluralismo político, económico, jurídico, cultural y lingüístico, dentro del proceso integrador del país". (BOLÍVIA, 2009).

E como pontua Cunha Filho (2018), esse Estado Plurinacional se constitui pela simbiose de três horizontes teóricos, o liberal, o indianista-comunitário e o nacional popular, de modo que a configuração territorial resultante desse processo, ainda que majoritariamente ancorada na pauta da hegemonia indígena-popular que se forjou nesse período, traz também em interior traços das minoritárias - mas poderosas - elites econômicas regionais ligadas ao mercado internacional e às verticalidades territoriais, consequência principalmente em razão do quórum de 2/3 para a aprovação da nova Constituição, das inúmeras pressões no decurso do processo constituinte, bem como da ulterior negociação da redação do texto constitucional com os poderes constituídos.

Isso posto, e tendo em consideração que o novo Estado Plurinacional será um projeto em disputa entre as forças políticas do País desde o que dispõe a constituição de 2009, bem como em razão do questionamento motriz desse 
trabalho, que diz respeito às garantias constitucionais no vindouro processo de disputa pelo território. Esse processo, que significa a reafirmação e o reforço das horizontalidades, sempre foi a pauta central das reivindicações que deram origem a constituinte - descolonização do Estado, nacionalização dos recursos naturais resta expor, agora, quais foram os direitos e garantias constitucionalizados como ferramentas de emancipação territorial e contenção de eventuais avanços arbitrários.

Em nosso ver, a primeira garantia que a nova constituição traz diz respeito ao modelo de refundação do Estado escolhido pelo poder constituinte originário: o Estado Constitucional pela via da constituição democrática. Para Dalmau (2018, p. 21), com base em Pelayo (1991, p. 42), o estado constitucional pode ser definido como o "[...] modelo de Estado en el que prima la Constitución sobre la ley, la totalidade de los poderes públicos están sometidos a la Constitución y de san las condiciones de justiciabilidad y garantía de la Constitución que aseguran su normatividade.", sendo para este autor o Estado Constitucional simultâneamente objetivo e proceso, "Es un objetivo por cuanto se fundamento último es la constitucionalización del ordenamiento jurídico cimentado en la hegemonía de la constituición democrática" e processo "[...] por cuanto se construye transitando temporalmente hacia este objetivo" (DALMAU, 2018, p. 21), tendo esse Estado Constitucional a promoção do Estado social, que no caso Boliviano é também Plurinacional e Comunitário.

O poder constituinte originário boliviano embasou o processo de cambio no modelo de Estado Constitucional, sendo a constituição democrática, a Constituição de 2009, a manifestação democrática de seu povo a qual todos devem obediência e é o objetivo e o processo do Estado Plurinacional Boliviano, conferindo maior proteção e centralidade à soberania popular ante a histórica elite política que sempre comandou o país.

Dado o seu conteúdo libertador, inovador e majoritariamente comprometido com as relações territoriais horizontais, esse modelo de Estado adotado confere maior proteção à vontade popular como racionalidade que irá conduzir as ações na produção e uso do território desde o início de sua vigência, na medida em que impõe restrições à ação dos poderes constituídos e aos fatores reais de poder. $O$ art. 411, I, da Constituição estabelece que todos estão submetidos à ela, e o inciso II do mesmo artigo estabelece a supremacia constitucional ante qualquer outra disposição normativa, o Art. 196, por sua vez, prevê o controle de constitucionalidade e o Tribunal Constitucional Plurinacional como guardião da vontade popular. (BOLÍVIA, 2009). Esses dispositivos buscam assegurar a primazia da constituição e assegurar o seu papel emancipador e de transição.

No âmbito mais propriamente dito de direitos e garantias constitucionais às horizontalidades, as inovações foram significativas. Primeiramente destacamos o reconhecimento em sede constitucional de agentes sociais historicamente marginalizados do direito constitucional do país: os povos e nações indígenas e originários. Ainda que em 1994 tenha ocorrido uma reforma constitucional incorporando o caráter pluriétnico, por primeira vez, nada se compara ao promovido pela constituição de 2009. $O$ art. $2^{\circ}$ da Constituição reconhece não só a existência pré-colonial das nações e povos indígenas originário campesino como 
também assegura o domínio sobre seus territórios, livre determinação, autonomia, autogoverno e reconhecimento de suas culturas e instituições. (BOLÍVIA, 2009). Esse artigo é basilar e é desenvolvido no decorrer de todo o texto constitucional e na sala das máquinas do Estado Plurinacional.

$\mathrm{O}$ artigo seguinte, $\mathrm{o} 3^{\circ}$, reforça o caráter plurinacional e intercultural da nova cidadania boliviana, ao explicitar que o povo boliviano será composto "[...]la totalidad de las bolivianas y los bolivianos pertenecientes a las áreas urbanas de diferentes clases sociales, a las naciones y pueblos indígena originario campesinos, y a las comunidades interculturales y afrobolivianas". (BOLÍVIA, 2009). A menção detalhada da composição do povo denota, em nosso modo de ver, um rechaço às concepções monoculturalistas ou multiculturalistas de povo, para consignar a vocação plural da nacionalidade boliviana, se assegurando o respeito à diversidade e da autodeterminação identitária intercultural.

Entretanto, conforme antecipamos, e bem demonstra o comentado art. $2^{\circ}$, não se trata meramente de um reconhecimento de direito positivo sem maiores reflexos institucionais. Ao revés, retomando o dito mais acima nesse trabalho, o princípio de plurinacionalidade representa como que a aplicação da autodeterminação nas entranhas do Estado, que deve assegurar, então, desdobramentos territoriais e institucionais.

E assim é que o art. $9^{\circ}$ estabelece um dos fins do Estado Plurinacional a obrigatoriedade de prover meios para o desenvolvimento e consolidação de identidades plurinacionais, culturais e territoriais, no marco intercultural e plurilíngue, assegurando como modo de construção de legitimidade no exercício do poder político a forma comunitária de democracia art. 11. (BOLÍVIA, 2009).

A constituição dedica todo um capítulo, o quarto, a elencar mais sistematicamente os direitos dos povos e nações indígenas originários campesinos, composto pelos artigos 30-32, de grande extensão, constitucionalizando sua personalidade coletiva, a identidade cultural, idioma, tradição histórica, instituições e territorialidade, com livre determinação territorial - no marco da unidade de Estado - reflexo de suas instituições no seio estatal, tutela de lugares sagrados, o direito à consulta prévia, etc., com detalhe para a extensão desses direitos e garantias ao povos afrobolivianos art. 32. (BOLÍVIA, 2009).

$\mathrm{Na}$ terceira parte da constituição, que trata da estrutura e organização territorial do Estado, é que se desenha mais propriamente a geografia política do Estado Plurinacional. E uma vez mais há um nítido empenho de delinear um modelo territorial que possibilite aos agentes sociais, em especial àqueles historicamente excluídos, ao deixar muito bem assentados os entes territoriais, suas atribuições e competências, o dever de promover o desenvolvimento territorial, sempre no marco da racionalidade predominante na constituição, majoritariamente nacionalista, pluralista e intercultural.

Segundo o art. 269, I, "Bolivia se organiza territorialmente en departamentos, provincias, municipios y territorios indígenas originarios campesinos". O inciso II determina que a criação, modificação e delimitação de entidades territoriais somente após consulta democrática de seus habitantes. O Art. 270 traz um extenso rol de princípios que regem a organização territorial, dentre eles a unidade, autogoverno, voluntariedade, preexistência das nações e povos indígenas, controle social e participação, dentre outros. (BOLÍVIA, 2009). 
A constituição prevê ainda autonomia departamental (art. 277), regional (Art. 280), composta por municípios ou províncias nos limites do departamento em que estejam; autonomia municipal (art. 283) e autonomia indígena originária campesina (Art. 289), permitindo a conformação de mancomunidades entre municípios, regiões e território indígenas. (BOLÍVIA, 2009).

$\mathrm{O}$ art. 272 determina que a autonomia implica "[...] la elección directa de sus autoridades por las ciudadanas y los ciudadanos, la administración de sus recursos económicos, y el ejercicio de las facultades legislativa, reglamentaria, fiscalizadora y ejecutiva, por sus órganos del gobierno autónomo en el ámbito de su jurisdicción y competencias y atribuciones". Já no que diz respeito à autonomia indígena e campesina, art. 289, "[...] ]consiste en el autogobierno como ejercicio de la libre determinación de las naciones y los pueblos indígena originario campesinos, cuya población comparte territorio, cultura, historia, lenguas, y organización o instituciones jurídicas, políticas, sociales y económicas propias.", sendo assim qualificados os territórios indígenas originários, os municípios e regiões que decidam democráticamente por essa condição (Art. 291). (BOLÍVIA, 2009).

A norma básica das entidades territoriais é o Estatuto ou a Carta Orgânica a ser redigida por seus órgãos deliberativos e aprovados por 2/3 e prévio controle de constitucionalidade, a ser exercido pelo Tribunal Constitucional Plurinacional (Art. 275), cumprindo aqui o Tribunal Constitucional o papel de assegurar que a ordenação territorial se dê em consonância com a constituição, mais um limite aos arbítrios dos fatores reais de poder.

E como se pode perceber, trata-se de uma complexa organização territorial, marcadamente descentralizada, em que a autonomia é acedida por vontade democrática, desfrutando as entidades autônomas de igualdade hierárquica, vedando-se a subordinação entre elas (Art. 276). As competências e atribuições de cada ente são dividas em privativas, reservadas ao poder central; exclusivas, as que são reservadas a um nível de governo; concorrentes; exercidas entre o nível central do Estado e os demais entes e compartidas, em que à Assembleia Legislativa Plurinacional cabe a edição de normas gerais e aos entes autônomos a posterior complementação. (Art. 297). (BOLÍVIA, 2009).

\section{Considerações finais}

Retomando a discussão acerca de como as garantias constitucionais podem servir à reafirmação das horizontalidades geográficas, entendemos que apesar de complexo, o modelo de organização territorial desenhado pela Constituição de 2009 possui grande potencialidade de assegurar meios de uso contra hegemônico do território aos agentes sociais historicamente excluídos da política territorial da Bolívia, visto que fruto de um igualmente complicado processo constituinte com compromissos de emancipação e refundação do Estado. E por prever o reconhecimento constitucional das territorialidades plurinacionais e interculturais provenientes dos povos e nações indígenas originários campesinos, e um ente territorial no qual possam criar essas territorialidades com a proteção do Estado. Uma nova realidade que parte do princípio de que o Estado deve estar comprometido com a plurinacionalidade. 
No que tange às históricas desigualdades regionais, a causa é fortemente atribuída ao histórico Estado aparente, bem como as rivalidades entre departamentos, principalmente os do oriente onde sob a liderança de Santa Cruz de la Sierra, buscava garantir meios de seguir com seu uso corporativo do território. A constituição, ao menos em tese, também trouxe soluções para esse impasse. Constituição que, logo em seu art. $1^{\circ}$ traz o processo de integração do país, um dos fundamentos do Estado Plurinacional da Bolívia.

Ainda quanto à sanha do oriente de ter nas autonomias sua trincheira de resistência ao processo, cabe ressaltar que logrou incluir as autonomias departamentais, que Ihes garantiam maior autonomia na gestão e uso do território, o que num primeiro momento já pode parecer que conseguiram cobertura jurídica para manter as pretéritas dinâmicas de uso do território.

Entretanto, na medida em que o processo de cambio está aferrado a um Estado Constitucional, que manteve o papel do nível central de governo em questões estratégicas e centralizado desde uma constituição democrática que goza de supremacia, a instauração das autonomias departamentais não pode destoar muito da vontade do poder constituinte originário. Além disso, o próprio mecanismo de aprovação dos Estatutos e Cartas Orgânicas, ao prever como etapa uma consulta prévia de constitucionalidade ao Tribunal Constitucional Plurinacional, impõe restrições aos possíveis impulsos deturpadores dos poderes departamentais.

Assim, retomando o que foi dito na introdução desse trabalho, já completados 10 anos de vigência, cumpre-nos, doravante, observar como tem sido conduzido esse processo, apontando seus avanços e limitações na luta diuturna pelo uso contra-hegemônico do território.

\section{REFERÊNCIAS}

ACHURY, Liliana Estupiñán. Modelos territoriales para estados plurales y diversos: el caso colombia. In: ACHURY, Liliana Estupiñán; GONZÁLEZ, Gabriel Moreno; MÁRQUEZ, Antônio Montiel (ed.). La cuestión territorial a debate: españa y colombia. España y Colombia. Bogotá: Universidad Libre, 2018. p. 215-238. Sérgio Franco.

ANTAS JR., Ricardo Mendes. Território e regulação - espaço geográfico: fonte material e não formal do direito. São Paulo: Humanitas; 2005.

BAGGIO, Roberta Camineiro. Federalismo no contexto da nova ordem global: perspectivas de (Re)formulação da federação brasileira. Curitiba: Juruá, 2014. $5^{\text {a }}$ reimpr.

BELLO, Enzo. A cidadania no constitucionalismo latino-americano. 2. ed. Rio de Janeiro: Lumen Juris, 2018.

CAPDEQUI, José María Ots. El estado español en las Índias. México: Fondo de Cultura Económico, 1993.

CATAIA, Márcio. Território usado e federação: articulações possíveis. Educ. Soc., Campinas, v. 8, n. 125, p.1135-1152, dezembro de 2013. 
CUNHA FILHO, Clayton Mendonça. Formação do estado e horizonte plurinacional na Bolívia. Curitiba: Appris, 2018.

DALMAU, Rubén Martínez. El proceso constituyente: la activación de la soberanía. In: GALVÁN, Íñigo Errejón; SERRANO, Alfredo (org.). ¡Ahora es cuándo, carajo!: del asalto a la transformación del estado en bolivia. Del asalto a la transformación del Estado en Bolivia. Madrid: Ediciones de Intervención Cultural/el Viejo Topo, 2011. p. 37-62.

DALMAU, Rubén Martínez. Qué implica un Estado Constitucional?: democracia, estado social y globalización. In: COUTINHO, Sayonara Grillo; SILVA, Lernardo da; BALMANT, Lilian (org.). Reformas institucionais de austeridade, democracia e relações de trabalho. São Paulo: Ltr, 2018. p. 21-31.

DALMAU, Rúben Martínez; PASTOR, Roberto Viciano. Fundamento teórico del nuevo constitucionalismo latinoamericano. In: VICIANO PASTOR, Roberto (Editor). Estudios sobre el nuevo constitucionalismo latinoamericano. Valencia: Tirant lo Blanch, 2012. p. 11-49.

DARDOT, Pierre; LAVAL, Christian. A nova razão do mundo: ensaio sobre a sociedade neoliberal. São Paulo: Boitempo, 2016.

DINIZ, Alexandre M. Alves; CAMPOLINA, Maíra. Raízes histórico-geográficas da formação e dilapidação do território boliviano. Geografia, Rio Claro, v. 31, n. 3, p. 505-526, dezembro de 2006. Quatrimestral. Disponível em: ebook. Acesso em: 15 abr. 2020

GALEANO, Eduardo. As veias abertas da América Latina. Porto Alegre: L\&pm Pocket, 2017. Tradução:

GALLUP, John Luke, GAVIRIA, Alejandro \& LORA, Eduardo. Geografia é destino? São Paulo: UNESP, 2007.

GALVÁN, Íñigo Errejón. Geografía del proceso político boliviano: nuevo modelo de estado e territorialización del conflito. New Cultural Frontiers, -, v. 1, p. 77-100, 2010. Disponível em:

https://www.academia.edu/1385576/_Geograf\%C3\%ADa_del_proceso_pol\%C3\%ADtic o_boliviano._Nuevo_Modelo_de_Estado_y_Territorializaci\%C3\%B3n_del_Conflicto_. Acesso em: 25 maio 2020.

GALVÁN, Iñigo Errejón. La Constitución boliviana y la refundación del Estado. Un análisis político. Papeles de Relaciones Ecosociales y Cambio Global, n. 107, p. 117-128, 2009.

GARGARELLA, Roberto. La sala de máquinas de la constitución: dos siglos de constitucionalismo en América Latina (1810 - 2010). Buenos Aires: Katz Editores, 2016.

HARVEY, David. A loucura da razão econômica: Marx e o capital no século xxi. São Paulo: Boitempo, 2018. Tradução: Artur Renzo. 
IAMAMOTO, Sue Angélica Serra. O nacionalismo boliviano em tempos de plurinacionalidade: Revoltas antineoliberais e constituinte (2000-2009). Dissertação de mestrado. Departamento de Ciência Política da Universidade de São Paulo, São Paulo, 2011.

LEONEL JÚNIOR, Gladstone. O novo constitucionalismo latino-americano: um estudo sobre a Bolívia. 2. ed. Rio de Janeiro: Lumen Juris, 2018.

LINERA, Álvaro García (ed.). Del Estado aparente al Estado Integral. In: INSTITUTO INTERNACIONAL PARA LA DEMOCRACIA Y LA ASISTENCIA ELECTORAL (IDEA INTERNACIONAL) (Bolívia) (ed.). Miradas: nuevo texto constitucional. La Paz: Instituto Internacional Para La Democracia y La Asistencia Electoral (idea Internacional), 2010b. p. 11-18. Disponível em: https://www.idea.int/publications/catalogue/miradas-nuevo-texto-constitucional . Acesso em: 20 maio 2020.

LINERA, Álvaro García. A potência plebeia: ação coletiva e identidades indígenas, operárias e populares na Bolívia. São Paulo: Boitempo, 2010a. Tradução: Mouzar Benedito e Igor Ojeda

MARX, Karl; ENGELS, Friedrich. Manifesto do partido comunista. São Paulo: Expressão Popular, 2008.

PAVANI, Giorgia; ACHURY, Liliana Estupiñán. Mutaciones del Estado Unitário en América Latina: Nuevos Rasgos Metodológicos para el Estudio de los Processos de Descentralización. In: PAVANI, Giorgia; ACHURY, Liliana Estupiñán (Org.).

Plurinacionalismo y Centralismo: tensiones del estado unitario en América Latina. Bogotá: Universidad Libre, Università di Bologna, 2017. p. 101-159.

SANTOS, Boaventura de Sousa. La Globalización del Derecho: los nuevos caminos de la regulación y emancipación. Bogotá: Unibiblos, 1998. Tradução: César Rodríguez.

SANTOS, Boaventura de Sousa. Renovar a teória crítica e reiventar a emancipação social. São Paulo: Boitempo, 2007.

SANTOS, Milton. Por uma outra globalização: do pensamento único a consciência universal. São Paulo: Record, 2000.

SANTOS, Milton. Os espaços da globalização. In. Da Totalidade ao lugar. São Paulo Edusp, 2005. p. 22-41.

SANTOS, Milton. A natureza do espaço: técnica e tempo. razão e emoção. 4. ed. São Paulo: Editora da Universidade de São Paulo, 2006.

SASSEN, Saskia. Territorio, autoridad y derechos: de los ensamblajes medievales a los ensamblajes globales. Buenos Aires: Kartz, 2010. Trad.: María Victoria Rodil.

SASSEN, Saskia. Una sociología de la globalización. Bogotá: Kartz, 2015. Trad.: María Victoria Rodil. 
SEBBEN, Fernando Dall'onder. Bolívia: logística nacional e construção do estado. 2010. 188 f. Dissertação (Mestrado) - Curso de Ciência Política, Instituto de Filosofia e Ciências Humanas, Universidade Federal do Rio Grande do Sul, Porto Alegre, 2010.

TOLEDO JUNIOR, Rubens de. Verticalidades, horizontalidades e o período popular da história. In: Rubens de Toledo Junior; Maria Auxiliadora da Silva; Clímaco César Siqueira Dias. (Org.). Encontro com o Pensamento de Milton Santos: $O$ lugar fundamentando o período popular da história. 01 ed.Salvador: Empresa Gráfica da Bahia, 2005, v. 01, p. 63-70.

VALENÇA, Daniel Araújo. De costas para o império: o Estado Plurinacional da Bolívia e a luta pelo socialismo comunitário. Rio de Janeiro: Lumen Juris, 2018.

ZEGADA, María Teresa. Las identidades y las especificidades socio-políticas regionales como condiciones para la construcción autonómica In: MINISTERIO DE AUTONOMÍAS (Org.). Ensayos sobre la autonomía en Bolivia. Serie autonomías para la gente. La Paz: Ministerio de Autonomías, 2012. p. 89-101.

Rubens de Toledo Junior. Possui bacharelado e licenciatura em Geografia pela Universidade de São Paulo (1995), estágio de pesquisa na Universidade de Paris I, Panthéon-Sorbonne (1998) e doutorado em Geografia Humana pela Universidade de São Paulo (2003). Professor dos cursos de Geografia e do Mestrado Interdisciplinar em Estudos Latino-Americanos pela Universidade Federal da Integração Latino-Americana.rubens70@gmail.com

Luiz Fernando Ribeiro de Sales. Advogado OAB/PR 100.509. Mestrando em Estudos Latino-Americanos pela Universidade Federal da Integração LatinoAmericana. Pesquisador vinculado aos grupos de pesquisa CESPI-América do Sul e Redes, Política e Território da mesma universidade. Membro da Rede para o Constitucionalismo Democrático-Brasil.advluiz.sales@gmail.com

\section{Submetido em: 31/05/2020}

\section{Aprovado em: 25/08/2020}

Como citar: DE TOLEDO JUNIOR, Rubens; RIBEIRO DE SALES, Luiz Fernando. O Estado Plurinacional da Bolívia e as garantias constitucionais à reafirmação das horizontalidades geográficas. Redes (St. Cruz Sul, Online), Santa Cruz do Sul, v. 25, p. 2640-2667, 2020. ISSN 1982-6745. doi:https://doi.org/10.17058/redes.v25io.15266. 


\section{CONTRIBUIÇÃO DE CADA AUTOR}

a. Fundamentação teórico-conceitual e problematização: Rubens de Toledo Junior, Luiz Fernando Ribeiro de Sales.

b. Pesquisa de dados e análise estatística: Rubens de Toledo Junior, Luiz Fernando Ribeiro de Sales.

c. Elaboração de figuras e tabelas: Rubens de Toledo Junior, Luiz Fernando Ribeiro de Sales. d. Fotos: não se aplica.

e. Elaboração e redação do texto: Rubens de Toledo Junior, Luiz Fernando Ribeiro de Sales. f. Seleção das referências bibliográficas: Rubens de Toledo Junior, Luiz Fernando Ribeiro de Sales.

Fontes de financiamento: Universidade Federal da Integração Latino-Ameriana, Pró-Reitoria de Pesquisa e Pós-Graduação. 